Ashil: Jurnal Pendidikan Anak Usia Dini

Vol. 1 No. 1, April 2021. e-ISSN: 2776-4117

https://doi.org/10.33367/piaud.v1i1.1518

Journal Ashil

Submitted:

Revised:

19-01-2021

27-01-2021

Accepted:

Published:

09-04-2021

24-04-2021

\title{
Perbedaan Pola Hubungan antara Orang Tua dan Anak Usia Dini Ditinjau dari Tingkat Stres Pengasuhan pada Masa Pandemi Covid-19
}

\author{
Nur Fatwikiningsih ${ }^{1}$, Lathifatul Fajriyah ${ }^{2}$ \\ Institut Agama Islam Tribakti \\ ${ }^{1}$ chaterinalongdress@gmail.com, ${ }^{2}$ latifatul.fajriyah03@gmail.com
}

\begin{abstract}
Abstrak
Masa pandemi COVID-19 berdampak pada dinamika keluarga salah satunya pada stres pengasuhan anak usia dini. Tujuan penelitian untuk mengetahui perbedaan pola hubungan antara orang tua dan anak usia dini ditinjau dari tingkat stres pengasuhan pada masa pandemi COVID-19. Sampel penelitian ditentukan dengan random sampling terdiri dari 53 orang Ayah dan 92 orang Ibu yang memiliki putra atau putri bersekolah di salah satu dari 36 Lembaga PAUD se-Kecamatan Gresik. Kuesioner child parent relationship scale dan child parent relationship scale (Skala hubungan orang tua-anak/CPRS) dibagikan melalui google form yang diisi oleh Ayah Bunda secara terpisah. child parent relationship scale (Skala hubungan orang tua-anak/CPRS) untuk mengukur pola hubungan orang tua-anak dan Parental Stress Scale (PSS) untuk mengukur tingkat stres pengasuhan. Analisis statistik menggunakan uji chi square dan hasil penelitian ini menunjukkan bahwa stres pengasuhan yang dialami orang tua sangat berpengaruh pada pola hubungan orang tua dan anak usia dini yakni nilai signifikansi kurang dari $0,05(0,000<0,05)$. Selain itu ada perbedaan signifikan pola hubungan antara Ibu dan anak usia dini ditinjau dari tingkat stres pengasuhan pada masa pandemi COVID-19 (nilai signifikansi kurang dari 0,05 atau $0,003<0,05$ ) sedangkan pada Ayah sebaliknya tidak ada perbedaan signifikan nilai signifikansi lebih dari 0,05 atau 0,081>0,05).
\end{abstract}

Kata kunci: COVID 19, Stres pengasuhan, Pola Hubungan

\begin{abstract}
The COVID-19 pandemic impacting the family dynamics, one of which is parenting stress take care of their early childhood. This study aimed to investigate the pattern of parent-child relationships during early childhood and the levels of parenting stress during the COVID-19 pandemic. The research sample was determined by random sampling. A sample consists of 53 fathers and 92 mothers who have sons or daughters attending school in one of 36 PAUD institutions in the Gresik District. Child parent relationship scale (CPRS) and Parental Stress Scale (PSS) were administered to 145 parents via the Google Form separately for the Mother and Father. Child parent relationship scale (CPRS) to measure parent-child relationship patterns and Parental Stress Scale (PSS) to measure the levels of parenting stress. Results with chi-square analysis found parenting stress impact on the pattern of parent-child relationships during early childhood significantly value
\end{abstract}


is less than $0.05(0,000<0.05)$. Also, there is a significant difference in the pattern of mother-child relationships during early childhood in terms of parental stress levels during the COVID-19 pandemic (significance value less than 0.05 or 0.003 $<0.05$ ) but not significantly for father-child relationships (significance value over from 0.05 or $0.081>0.05$ ).

Keywords: COVID-19, Parenting Stress, The Pattern Relationships

\section{PENDAHULUAN}

Wabah COVID-19 berdampak pada well being (kesejahteraan) individu dan masyarakat. Kesejahteraan masyarakat di sini berkaitan dengan kesehatan fisik dan psikologis (kesehatan mental), kondisi ekonomi domestik rumah tangga, rasa aman-nyaman, serta kualitas hidup individu. Secara psikologi konteks individu dan kontekstual saling berkaitan. Dalam menanggapi situasi yang penuh stres proses konteks individu dan kontekstual saling berkaitan (Kloos et. al., 2012: 256). Kondisi lingkungan yang sedang dalam wabah bencana COVID-19 ini akan berinteraksi dan berdampak langsung dalam berbagai domain kehidupan. Kebijakan yang Pemerintah keluarkan bukan pemicu langsung dari suatu masalah tetapi melibatkan kerentanan yang secara tidak langsung terkait dengan masalah. Misalnya social distancing, study from home, work from home, dan kebijakan di bidang ekonomi lainnya akan berdampak pada dinamika masyarakat, dinamika keluarga, dan juga kondisi psikologis individual.

Keluarga-keluarga di dunia harus mampu menyesuaikan dengan berbagai perubahan yang sedang terjadi karena wabah COVID-19 ini. Banyak orang tua yang merasa stres karena harus menyeimbangkan antara pekerjaan, merawat anak, dan pekerjaan rumah, terutama pada saat mereka terpisah dengan jejaring pendukung yang biasa mereka miliki walaupun isolasi bisa membawa kesempatan untuk menghabiskan waktu bersama dan mengembangkan hubungan anda dengan anakanak anda, banyak pengasuh utama/orangtua yang tentunya akan mengalami konflik perasaan dan prioritas, dan juga tantangan-tantangan praktis lainnya. Hal ini tentunya akan berdampak pada baik buruknya pola hubungan antara orang tua dan anak dan juga perkembangan anak.

PAUD merupakan suatu upaya pembinaan yang ditujukan kepada anak sejak lahir sampai dengan usia 6 tahun yang dilakukan melalui rangsangan pendidikan 
untuk membantu pertumbuhan dan perkembangan jasmani dan rohani agar anak memiliki kesiapan belajar dalam memasuki pendidikan lebih lanjut (Peraturan Menteri Pendidikan dan Kebudayaan Republik Indonesia Nomor 146 Tahun 2014). Masa usia dini adalah masa emas perkembangan anak dimana semua aspek perkembangan dapat dengan mudah distimulasi. Periode emas ini hanya berlangsung satu kali sepanjang rentang kehidupan manusia. Oleh karena itu, pada masa usia dini perlu dilakukan upaya pengembangan menyeluruh yang melibatkan aspek pengasuhan, kesehatan, pendidikan, dan perlindungan.Masa ini berlangsung mulai dari umur 2 tahun sampai 6 tahun yakni masa masa prasekolah, dimana anak umumnya masuk Kelompok Bermain dan Taman Kanak-Kanak (Santrock, 2012). Umumnya orang tua menganggap masa ini sebagai usia bermasalah atau usia sulit karena pada masa ini sering terjadi masalah perilaku sebagai akibat karena anak sedang dalam proses perkembangan kepribadian yang unik dan menuntut kebebasan yang pada umumnya masih kurang berhasil. Seringkali anak usia dini bersikap bandel, keras kepala, tidak menurut, melawan, dan marah tanpa alasan. Sering juga dianggap sebagai usia bermain karena senang menghabiskan sebagian besar waktunya untuk bermain. Maka dari itu peran pengasuhan orang tua sangat penting sebagai pondasi dasar untuk perkembangan selanjutnya. Apalagi dengan kondisi pandemi COVID-19 orang tua lebih banyak berperan untuk pengasuhan di rumah baik Ayah maupun Ibu.

Hasil studi literatur menunjukkan bahwa hubungan orang tua-anak berkaitan dengan perkembangan akademik, sosial, emosional anak-anak. Bowlby tahun 1982 menyatakan bahwa perilaku orang tua dalam hubungan orang tuaanak sebagai sistem pengasuhan sebuah sistem perilaku yang berbeda-beda pemberian perhatian antara ayah dan ibu. Gambaran hubungan bisa berdampak pada perkembangan sosial emosional dan kinerja di sekolah (Driscoll, Kate \& Pianta, Robert C, 2011: 2). Perkembangan hubungan yang kompeten dengan teman sebaya dianggap sebagai satu-satunya tugas yang sangat penting pada masa kanakkanak dan anak-anak yang interaksi sehari-harinya dengan orang tuanya seperti bermain pura-pura, bercanda, negosiasi konflik, bersepakat standar perilaku, dan percakapan dalam keluarga memberikan anak sebuah konteks alamiah untuk 
belajar mengenai dunia sosial (Driscoll, Kate \& Pianta, Robert C, 2011: 3). Seorang anak yang merasakan kehangatan dalam afeksi di lingkaran keluarganya pastinya akan lebih positif dalam membangun hubungan sosial dengan orang lain dengan orang lain (Jiun, et al., 2016: 157).

Hubungan antara orang tua dengan anak seringkali berfungsi sebagai moderator dan mediator (perantara) ketika anak dihadapkan dengan resiko khusus. Kualitas interaksi orang tua-anak selama usia prasekolah bermanfaat untuk perkembangan regulasi emosi anak-anak dan menyumbang proporsi variasi yang signifikan dalam peringkat kinerja akademik mereka, keterampilan sosial dengan teman sebaya, dan keseluruhan masalah perilaku anak dan skor kompetensi (Smith, 2009). Terlepas dari status sosial ekonomi dan etnis, kualitas interaksi antara orang tua dengan anak yang hangat dan responsif emosional dikaitkan dengan kesiapan sekolah anak-anak, yang mencakup peringkat yang lebih tinggi pada keterampilan sosial dan kemampuan komunikasi reseptif (Connell \& Prinz, 2002). Hubungan antara orang tua dengan anak juga menjadi prediktor akan perilaku pengasuhan.

Hubungan orang tua-anak terbagi menjadi tiga pola yakni dekat, konflik, dan tergantung (Pianta, 1992). Hubungan orangtua-anak yang dekat berupa hubungan afektif yang hangat, mendukung sikap positif, menerima,komunikasi terbuka, dan keterlibatan (Smith, 2009). Di sisi lain, hubungan konflik orang tua dengan anakanak mereka ditandai oleh tingkat sensitivitas dan ketersediaan yang rendah (Smith, 2009). Hubungan orang tua-anak yang konflik menunjukkan sering berselisih, interaksi yang sumbang, dan kurangnya hubungan antara orang tua dengan anak. Hubungan antara orang tua dengan anak dependen/tergantung ditandai dengan perilaku anak yang posesif, melekat, dan terlalu bergantung pada orang tua (Fraire, et al., 2013: 858).

Stres pengasuhan umumnya didefinisikan sebagai serangkaian proses yang mengarah pada reaksi psikologis dan fisiologis yang tidak diinginkan dalam upaya untuk beradaptasi dengan tuntutan menjadi orang tua (Kochanova, 2014: 852). Definisi lainnya stres pengasuhan dijelaskan sebagai rasa cemas dan rasa tegang secara berlebihan yang dialami orang tua ketika menjalankan peran sebagai orang 
tua, serta dapat muncul ketika adanya hambatan atau kekurangan pada hubungan interaksi antara orang tua dan anak (Abidin, 1995). Selain dampaknya pada kesehatan mental orang tua dan masalah perilaku anak, tingkat stres orangtua yang tinggi berulang kali terbukti berdampak negatif terhadap berbagai faktor hubungan orang tua-anak seperti kepekaan ibu.

Sebagian besar penelitian yang meneliti masalah perilaku anak dan stres dalam mengasuh anak hanya melibatkan ibu. Penelitian terdahulu menunjukkan ada kesamaan pendapat antara ayah dan ibu tentang masalah perilaku pada anak usia 3 dan 4 tahun, terutama di antara orang tua dari anak-anak dengan keterlambatan, serta hubungan yang sama antara masalah perilaku anak dan stres orang tua untuk ibu dan ayah (Neece, et al., 2012: 4). Dengan demikian kita tidak tahu apakah hubungan antara masalah perilaku anak dan stres pengasuhan dari waktu ke waktu adalah sama untuk ibu dan ayah (Neece, et al., 2012: 4). Stres pengasuhan yang tinggi merupakan variabel risiko lingkungan yang penting (Neece, et al., 2012: 3). Hal ini telah terbukti menghasilkan sesuatu yang tidak diinginkan seperti depresi orang tua, konflik perkawinan, kesehatan fisik yang lebih buruk, pengasuhan yang kurang efektif dan masalah perilaku anak (Neece, et al., 2012: 3).

Kondisi stres pengasuhan yang berkurang menyebabkan perubahan positif dapat terjadi dalam hubungan orangtua-anak, yang dapat mendukung perilaku pengasuhan yang lebih efektif (Lewallen, 2015). Orang tua yang mengalami stres dalam peran pengasuhan mereka cenderung menampilkan pengasuhan yang lebih negatif dan keras, interaksi yang kurang mendukung dan kurang peduli dengan anak-anak mereka. Hasil riset menunjukkan lebih banyak masalah perilaku anak dibandingkan orang tua yang mengalami lebih sedikit stres (Cabrera \& Mitchell, 2009: 2). Beberapa tahun terakhir riset telah berfokus pada peran yang dimainkan ayah dalam keluarga, khususnya keterlibatan laki-laki minoritas berpenghasilan rendah dengan anak-anak mereka (Cabrera \& Mitchell, 2009: 2). Penelitian ini menunjukkan bahwa ada keterlibatan pengasuhan di antara ayah dan ibu dan bahwa di antara ayah berpenghasilan rendah, dan mayoritas ayah berpenghasilan rendah yang bukan penduduk terlibat dan terlibat dalam anak-anak mereka hidup. 
Akibatnya, ayah yang terlibat dalam kehidupan anak-anak mereka dan berpartisipasi dalam rutinitas pengasuhan harian mungkin mengalami hal seperti stres orangtua seperti yang dilaporkan oleh para ibu. Hasil penelitian menunjukkan bahwa stres orangtua adalah anteseden dan konsekuensi dari masalah perilaku anak. Secara bersamaan, masalah perilaku anak merupakan anteseden dan konsekuensi dari stres orangtua (Lewallen, 2015).

Stres pengasuhan dialami oleh semua orang tua terlepas dari status sosial ekonomi. Semua orang tua harus menyeimbangkan dan memenuhi tuntutan pengasuhan yang kadang-kadang bisa membuat mereka stres (Kochanova, 2014: 852). Stres pengasuhan umumnya didefinisikan sebagai serangkaian proses yang mengarah pada reaksi psikologis dan fisiologis yang tidak diinginkan dalam upaya untuk beradaptasi dengan tuntutan menjadi orang tua (Kochanova, 2014: 852). Definisi lainnya stres pengasuhan dijelaskan sebagai rasa cemas dan rasa tegang secara berlebihan yang dialami orang tua ketika menjalankan peran sebagai orang tua, serta dapat muncul ketika adanya hambatan atau kekurangan pada hubungan interaksi antara orang tua dan anak (Abidin, 1995). Stres pengasuhan (Lestari, 2012) muncul disebabkan oleh beberapa faktor yakni yang pertama faktor yang berasal dari diri sendiri atau tingkatan individu, faktor ini dapat bersumber dari pribadi orang tua maupun anak. Kedua yakni faktor tingkatan keluarga, di mana masalah keluarga dan struktur keluarga dapat mendorong adanya stres pengasuhan. Faktor ketiga yakni dari tingkatan lingkungan dalam hal ini peneliti kaitkan dengan faktor kontekstual yakni masa wabah Covid-19. Mariana kepada BBC News Indonesia (Liza Tambunan, 2020) mengemukakan:

"Kita membaca banyak suara dari banyak perempuan yang sekarang harus di rumah, terutama perempuan yang bekerja, itu mengalami beban yang sangat berat karena mereka jadi terbebani urusan-urusan rumah. Mulai dari mengasuh anak, mengajar anak sekolah yang juga secara online. Pihak suami lebih banyak dalam posisi yang seperti biasanya, bahwa semua urusan rumah tangga harus dijalankan oleh istri. Jadi banyak sekali yang mengeluh sebetulnya karena situasi kerja di rumah ini". 
Salah satu pendekatan untuk mengukur stres pengasuhan adalah dengan teori hubungan transaksional timbal balik Parent-Child-Relationship (P-C-R) atau hubungan orang tua anak yang meliputi tiga domain yakni orang tua, anak, hubungan orang tua dan anak (dalam penelitian ini ayah, bunda dengan anak) (Kochanova, 2014: 853). Misalnya, masalah perilaku anak dapat menghasilkan stres pengasuhan pada orang tua dan mempengaruhi kesehatan mental orang tua dengan menghasilkan depresi. Pada saat yang sama depresi orang tua dapat menyebabkan orang tua kurang terlibat dengan anak sehingga menghasilkan problem perilaku pada anak. Domain hubungan orangtua anak mengandung aspek stres pengasuhan yang timbul dari dalam hubungan orangtua anak karena masalah dalam interaksi orangtua-anak, seperti konflik, permusuhan, dan keyakinan bahwa hubungan tersebut tidak memenuhi harapan dan tidak lagi bermanfaat (Kochanova, 2014: 853).

Selama ini orang tua memandang (mempersepsikan) hubungan mereka dengan anak-anak mereka dapat berbeda-beda yakni bisa dekat (hubungan positif), konflik, dan juga ketergantungan. Berdasarkan sebuah penelitian pada orang tua anak usia pra sekolah menunjukkan ibu lebih dekat dengan anak lakilaki maupun perempuannya dibandingkan dengan ayah dan ayah lebih dekat dengan anak perempuannya dibandingkan anak laki-laki (Driscoll et al., 2011: 6). Selain itu ibu juga mengalami peningkatan perasaan kedekatan dengan anakanaknya baik anak laki-laki atau perempuan selama periode waktu ini. Ibu melakukan sebagian besar pengasuhan dan menghabiskan lebih banyak waktu dengan anak-anak, mereka lebih mungkin mengalami stres pengasuhan anak (Cabrera \& Mitchell, 2009: 2). Penelitian lain menunjukkan bahwa di antara pasangan orang tua dari dua pasangan rumah tangga dalam pengasuhan telah meningkat dari waktu ke waktu (Bianchi, 2006; Yeung et al., 2001) dan menunjukkan Ayah berpenghasilan rendah terlibat dalam kehidupan anak-anak mereka (Cabrera, Ryan, Mitchell, Shannon, \& Tamis-LeMonda, 2008). Akibatnya, Ayah yang terlibat dalam kehidupan anak-anaknya dan berpartisipasi dalam rutinitas pengasuhan harian mungkin mengalami hal serupa stres orangtua seperti yang dilaporkan oleh para ibu. 
Pandemi global membuat ayah dan ibu membawa kesempatan untuk menghabiskan waktu bersama dan mengembangkan hubungannya dengan anakanak, banyak pengasuh utama/orangtua yang tentunya akan mengalami konflik perasaan dan prioritas, dan juga tantangan-tantangan praktis lainnya. Pengasuhan anak merupakan hal yang menantang bahkan pada saat keadaan baik-baik saja, tetapi di masa-masa sulit ini dan penuh dengan ketidakpastian sehingga resiko stres pengasuhan bisa muncul baik pada ayah dan ibu utamanya bagi mereka yang memiliki anak usia 2-6 tahun. Menurut Hurlock (1980)karakteristik anak usia dini cenderung sebagai usia yang sulit diatur karena memasuki tahap perkembangan kepribadian yang umumnya menuntut kebebasan. Hal ini ditunjukkan dengan perilaku bandel, keras kepala, tidak menurut dan melawan, sering marah tanpa alasan, serta ritme tidur yang tidak teratur. Secara psikologi anak-anak pada usia dua hingga enam tahun dikenal sebagai usia eksplorasi. Anak-anak mulai belajar nilai-nilai sosial di lingkungan sekitar untuk kehidupan bersosialnya di masa yang akan datang. Selain itu, anak-anak usia ini pun mengalami perkembangan utama berkisar di seputar penugasan dan pengendalian lingkungan.

Anak-anak usia dini yang sudah bersekolah di PAUD harus belajar di rumah dan peran orang tua dalam stimulasi tumbuh kembang anak sangat dominan karena pembelajaran dilakukan di rumah dan kegiatan bermain anak juga di rumah. Beberapa anak usia dini mungkin pada awalnya senang berada di rumah, tetapi seiring dengan waktu terjadi perubahan perasaan terhadap rutinitas mereka, terpisah dari teman dan pembatasan-pembatasan lain yang diterapkan akan meningkatkan stres mereka karena secara psikologi perkembangan masa usia ini adalah masa usia bermain, minat terhadap teman, mudah frustasi, suka bereksplorasi, masa peka, dan masa belajar dari pengalaman langsung. Berdasarkan uraian di atas dapat dirumuskan pertanyaan penelitian ini adalah Apakah ada perbedaan signifikan pola hubungan antara orang tua (Ayah Bunda) dan anak usia dini ditinjau dari tingkat stres pengasuhan pada masa pandemi COVID-19?. Apakah ada perbedaan signifikan pola hubungan antara Bunda (Ibu) dan anak usia dini ditinjau dari tingkat stres pengasuhan pada masa pandemi COVID-19?. Apakah ada perbedaan signifikan pola hubungan antara Ayah dan anak 
usia dini ditinjau dari tingkat stres pengasuhan pada masa pandemi COVID-19?, dengan hal ini diharapkan dapat memberikan pengetahuan khususnya pada orang tua untuk mengalokasikan rasa stress dengan tepat, karena jika tidak dialokasikan dengan tepat dapat berpengaruh terhadap pertumbuhan dan perkembangan anak.

\section{METODE}

Penelitian ini adalah penelitian kuantitatif dengan metode korelasi. Teknik sampling yang digunakan adalah random sampling dengan sampel terpakai, artinya peneliti memberikan kesempatan seluas-luasnya kepada siapapun untuk mengisi kuesioner dengan syarat responden merupakan Ayah Bunda yang memiliki putra atau putri bersekolah di salah satu dari 36 Lembaga PAUD seKecamatan Gresik dan putra-putrinya masih tercatat aktif pada tahun 2020. Waktu penelitian pada bulan 12 Mei sampai 18 mei 2020. Kuesioner yang digunakan adalah child parent relationship scale (Skala hubungan orang tua-anak/CPRS) yang diadopsi dari Dr. Robert Pianta, Ph.D. untuk mengukur pandangan orang tua tentang hubungan mereka dengan anak. Teknik analisis data menggunakan statistik uji square.

\section{HASIL DAN PEMBAHASAN}

Pertanyaan pertama dalam penelitian ini mengenai apakah ada perbedaan signifikan pola hubungan antara orang tua (Ayah Bunda) dan anak usia dini ditinjau dari tingkat stres pengasuhan pada masa pandemi COVID-19. Berdasarkan hasil analisis statistik menggunakan uji chi square ditunjukkan dalam tabel 1. Hasilnya menunjukkan nilai signifikansi p-value sebesar 0,000 dan nilai chi square 0,25892 karena nilai signifikansi kurang dari 0,05 $(0,000<0,05)$ maka Ho ditolak yang berarti terdapat perbedaan signifikan pola hubungan antara orang tua (Ayah Bunda) dan anak usia dini ditinjau dari tingkat stres pengasuhan pada masa pandemi COVID-19. Berdasarkan analisis data deskriptif dalam tabel 2 menunjukkan bahwa jumlah Ibu/Bunda yang mengalami tingkat stres tinggi 14\%, sedang 55\%, dan rendah 30\%. Frekuensi pola hubungan antara Ibu dan anak tipe dekat 39\%, konflik 35\%,dan dependen/tergantung 26\%. Jumlah Ayah yang 
mengalami tingkat stres sangat tinggi $2 \%$, tinggi 5\%, sedang $24 \%$, dan rendah 22\%. Frekuensi pola hubungan antara Ayah dan anak tipe dekat 34\%, konflik 38\%, dan dependen/tergantung $28 \%$.

Tabel 1.Uji chi square perbedaan pola hubungan antara orang tua (Ayah Bunda) dan anak usia dini ditinjau dari tingkat stres pengasuhan pada masa pandemi COVID-19.

\begin{tabular}{|c|c|c|c|}
\hline & Value & $\mathrm{df}$ & $\begin{array}{l}\text { Asymp. Sig. } \\
\text { (2-sided }\end{array}$ \\
\hline $\begin{array}{l}\text { Pearson Chi- } \\
\text { Square }\end{array}$ & $25.892^{\mathrm{a}}$ & 6 & .000 \\
\hline $\begin{array}{l}\text { Likelihood } \\
\text { Ratio }\end{array}$ & 27.606 & 6 & .000 \\
\hline $\begin{array}{l}\text { Linear-by- } \\
\text { Linear }\end{array}$ & 5.088 & 1 & .024 \\
\hline $\begin{array}{l}\text { Association } \\
\mathrm{N} \text { of Valid } \\
\text { Cases }\end{array}$ & 145 & & \\
\hline
\end{tabular}

Nilai signifikansi p-value dari uji chi square

Tabel 2. Data deskriptif perbedaan antara pola hubungan orang tua dan anak usia dini ditinjau dari tingkat stres pengasuhan pada masa pandemi COVID-19

\begin{tabular}{|c|c|}
\hline Variabel & $\mathrm{n} \%$ \\
\hline \multicolumn{2}{|l|}{ Ibu } \\
\hline \multicolumn{2}{|l|}{ Tingkat Stres } \\
\hline a. Sangat tinggi & $0 \%$ \\
\hline b. Tinggi & $14 \%$ \\
\hline c. Sedang & $55 \%$ \\
\hline d. Rendah & $30 \%$ \\
\hline \multicolumn{2}{|l|}{ Pola Hubungan } \\
\hline a. Dekat & $39 \%$ \\
\hline b. Konflik & $35 \%$ \\
\hline c. Tergantung/dependen & $26 \%$ \\
\hline \multicolumn{2}{|l|}{ Ayah } \\
\hline \multicolumn{2}{|l|}{ Tingkat Stres } \\
\hline a. Sangat tinggi & $2 \%$ \\
\hline b. Tinggi & $5 \%$ \\
\hline c. Sedang & $24 \%$ \\
\hline d. Rendah & $22 \%$ \\
\hline \multicolumn{2}{|l|}{ Pola Hubungan } \\
\hline a. Dekat & $34 \%$ \\
\hline
\end{tabular}




\begin{tabular}{lll}
\hline b. & Konflik & \\
c. & Tergantung/dependen & $38 \%$ \\
\end{tabular}

Hipotesis kedua dalam penelitian ini mengenai apakah ada perbedaan signifikan pola hubungan antara Bunda dan anak usia dini ditinjau dari tingkat stres pengasuhan pada masa pandemi COVID-19. Berdasarkan hasil analisis statistik menggunakan uji chi square ditunjukkan dalam tabel 3. Hasilnya menunjukkan nilai signifikansi p-value sebesar 0,003 dan nilai chi square 0,15705 karena nilai signifikansi kurang dari $0,05(0,003<0,05)$ maka Ho ditolak yang berarti terdapat perbedaan signifikan pola hubungan antara Bunda dan anak usia dini ditinjau dari tingkat stres pengasuhan pada masa pandemi COVID-19.

\begin{tabular}{|c|c|c|c|}
\hline & Value & $\mathrm{df}$ & $\begin{array}{l}\text { Asymp. Sig. } \\
\text { (2-sided) }\end{array}$ \\
\hline $\begin{array}{l}\text { Pearson Chi- } \\
\text { Square }\end{array}$ & $15.705^{a}$ & 4 & .003 \\
\hline $\begin{array}{l}\text { Likelihood } \\
\text { Ratio } \\
\text { Linear-by- }\end{array}$ & 16.643 & 4 & .002 \\
\hline $\begin{array}{l}\text { Linear } \\
\text { Association }\end{array}$ & 2.004 & 1 & .157 \\
\hline $\mathrm{N}$ of Valid Cases & 92 & & \\
\hline
\end{tabular}

Nilai signifikansi p-value dari uji chi square

Hipotesis ketiga dalam penelitian ini mengenai apakah ada perbedaan signifikan pola hubungan antara Ayah dan anak usia dini ditinjau dari tingkat stres pengasuhan pada masa pandemi COVID-19. Berdasarkan hasil analisis statistik menggunakan uji chi square ditunjukkan dalam tabel 4. Hasilnya menunjukkan nilai signifikansi p-value sebesar 0,081 dan nilai chi square 0,11251 karena nilai signifikansi lebih dari $0,05(0,081>0,05)$ maka Ho diterima yang berarti tidak ada perbedaan signifikan pola hubungan antara Ayah dan anak usia dini ditinjau dari tingkat stres pengasuhan pada masa pandemi COVID-19. 


\begin{tabular}{|c|c|c|c|}
\hline & Value & Df & $\begin{array}{l}\text { Asymp. Sig. } \\
\text { (2-sided) }\end{array}$ \\
\hline $\begin{array}{l}\text { Pearson Chi- } \\
\text { Square }\end{array}$ & $11.251^{\mathrm{a}}$ & 6 & .081 \\
\hline $\begin{array}{l}\text { Likelihood } \\
\text { Ratio }\end{array}$ & 13.124 & 6 & .041 \\
\hline $\begin{array}{l}\text { Linear-by- } \\
\text { Linear } \\
\text { Association }\end{array}$ & 3.401 & 1 & .065 \\
\hline $\begin{array}{l}\mathrm{N} \text { of Valid } \\
\text { Cases }\end{array}$ & 53 & & \\
\hline
\end{tabular}

Nilai signifikansi p-value dari uji chi square

Pengasuhan anak merupakan hal yang menantang bahkan pada saat keadaan baik-baik saja, tetapi di masa-masa krisis bencana COVID-19 ini dan penuh dengan ketidakpastian resiko stres pengasuhan bisa muncul baik pada ayah dan ibu utamanya bagi mereka yang memiliki anak usia dini (2-6 tahun). Hasil penelitian menunjukkan bahwa stres pengasuhan yang dialami orang tua sangat berpengaruh pada pola hubungan antara orang tua dengan anak usia dini. Hubungan antara orang tua dengan anak terbagi menjadi tiga pola yakni dekat, konflik, dan tergantung (Pianta, 1992). Pola hubungan orang tua-anak usia dini ini akan berdampak pada perilaku pengasuhan ibu. Bukti penelitian terdahulu menunjukkan bahwa hubungan dua arah sedemikian rupa sehingga stres pengasuhan anak yang lebih tinggi mengarah ke masalah perilaku anak yang lebih besar yang pada gilirannya terus memperburuk stres orangtua (Lewallen, 2015). Level stres yang tinggi berkaitan dengan dampak negatif pada anak-anak dan orang tua. Misalnya, orang tua yang sangat stres secara signifikan lebih rentan terhadap depresi orang tua, konflik perkawinan, dan kesehatan fisik yang lebih buruk (Lewallen, 2015), sedangkan dalam kondisi Covid-19 imunitas harus terpelihara dengan baik. Sebuah studi yang dilakukan Frontini dkk (2016) menjelaskan bahwa stres pengasuhan yang dialami oleh ibu dapat mempengaruhi kesehatan anak-anak. 
Stres pengasuhan merupakan respon dari perasaan negatif orang tua terhadap tuntutan dalam mengasuh anak, Deater-Deckard (dalam Cronin, Becher, \& Powell, 2015). Misalkan, orang tua mengalami stres karena tuntutan untuk segera memenuhi kebutuhan anak, orang tua mengalami hambatan untuk menyeimbangkan kebutuhan anak dan kebutuhan mereka sendiri, tekanan sosial, lingkungan, dan tanggung jawab terhadap kehidupan sehari-hari. Mayoritas penelitian yang meneliti hubungan orangtua-anak lebih berfokus pada hubungan antara ibu dengan anak daripada hubungan antara ayah dengan anak (Driscoll, 2011). Penelitian lain menyebutkan bahwa ibu yang menghadapi stres atau kekurangan dukungan yang memadai sering kali lebih banyak mengasuh anak kurang menyenangkan (Williamson \& McCabe, 2013). Hasil penelitian menunjukkan bahwa pada Ibu/Bunda ada perbedaan signifikan pola hubungan antara Ibu dan anak usia dini ditinjau dari tingkat stres pengasuhan pada masa pandemi COVID-19 sedangkan pada Ayah sebaliknya tidak ada perbedaan signifikan pola hubungan antara Ayah dan anak usia dini ditinjau dari tingkat stres pengasuhan pada masa pandemi COVID-19. Namun demikian secara deskriptif pola hubungan antara Ibu/Bunda dan anak usia dini pada masa pande mi COVID-19 menunjukkan cukup banyak pola hubungan bersifat negatif yakni tipe konflik dan dependen. Hal ini berlaku juga dengan pola hubungan antara Ayah dan anak usia dini pada masa pandemi COVID-19.

Temuan ini sesuai dengan pendekatan family systems theory yang menekankan saling ketergantungan hubungan keluarga dan pengaruhnya terhadap hasil anggota keluarga individu (Nomaguchi, et al., 2017). Menurut teori tersebut, apa yang ayah lakukan (atau tidak lakukan) memiliki implikasi untuk stres pengasuhan ibu sehingga juga berdampak pada pola hubungan antara orang tua dan anak. Hasil penelitian ini menunjukkan peran ibu dalam pengasuhan masih sangat dominan dibandingkan peran ayah dimana tingkat stres pengasuhan Ibu justru berhubungan dengan pola hubungan antara Ibu/Bunda dengan anak sedang tingkat stres pengasuhan yang dialami Ayah tidak ada pengaruhnya pada pola hubungan antara Ayah dan anak usia dini. Kerjasama co parenting ayah menggambarkan sejauh mana ayah mendukung upaya pengasuhan Ibu pada anak 
mereka dan bekerja dengannya secara efektif dalam membesarkan anak mereka (Nomaguchi, et al., 2017). Jika ayah berkolaborasi dengan para Ibu untuk menerapkan pendekatan pengasuhan yang seragam akan lebih mudah bagi para Ibu untuk menangani tuntutan pengasuhan sehingga tingkat stres pengasuhan Ibu bisa berkurang dan tidak begitu berdampak pada pola hubungan yang negatif antara Ibu dan anak usia dini begitu juga sebaliknya antara Ayah dan anak usia dini tersebut.

\section{SIMPULAN}

Hasil penelitian ini menunjukkan bahwa stres pengasuhan yang dialami orang tua sangat berpengaruh pada pola hubungan orang tua dan anak usia dini. Selain itu ada perbedaan signifikan pola hubungan antara Ibu dan anak usia dini ditinjau dari tingkat stres pengasuhan pada masa pandemi COVID-19 sedangkan pada Ayah sebaliknya tidak ada perbedaan signifikan. Namun demikian secara deskriptif pola hubungan antara Ibu/Bunda dan anak usia dini pada masa pandemi COVID-19 masih menunjukkan cukup banyak pola hubungan bersifat negatif yakni tipe konflik dan dependen. Hal ini berlaku juga dengan pola hubungan antara Ayah dan anak usia dini pada masa pandemi COVID-19. Peran ibu dalam pengasuhan masih sangat dominan dibandingkan peran Ayah. Ayah perlu berkolaborasi dengan para Ibu untuk menerapkan pendekatan pengasuhan yang seragam untuk mempermudah Ibu dalam menangani tuntutan pengasuhan selama masa pandemi COVID-19 sehingga tingkat stres pengasuhan Ibu bisa berkurang dan tidak begitu berdampak pada pola hubungan yang negatif antara Ibu dan anak usia dini begitu juga sebaliknya antara Ayah dan anak usia dini tersebut.

\section{REFERENSI}


Abidin, R. R., \& Brunner, J. F. (1995). Development of a parenting alliance inventory. Journal of Clinical Child Psychology, 24, 49-54. https://doi.org/10.1207/s15374424jccp2401.

Anshori, Feby Yutika. (2018). Positive Parenting Program (Triple-P) untuk Menurunkan Stres Pengasuhan Pada Ibu Dengan Anak Usia Kanak Kanak Awal. Universitas Muhammadiyah Malang.

Cabrera, Natasha., \& Mitchell, Stephanie. (2009). An exploratory study of fathers' parenting stress and toddlers' social development in low-income african american families. Fathering, 7(3), 201-225. doi:10.3149/fth.0703.201.

Deater-Deckard, K., Pickering, K., Dunn, J. F., \& Golding, J. (1998). Family structure, material status, and depressive in men preceding and following the birth of a child. American Journal of Psychology.

Deater-Deckard, K. (2004). Parenting Stress: Current Perspective in Psychology. New Haven and London: Yale University Press.

Driscoll, Kate., \& Pianta, Robert C. (2011). Mothers' and fathers' perceptions of confict and closeness in parent-child relationships during early childhood. Journal of Early Childhood and Infant Psychology, 7, 1-24.

Fraire, M., Longobardi, C., Prino L. E., Sclavo, E., \& Settanni, M. (2013). Examining the student-teacher relationship scale in the italian context: a factorial validity study. Electronic Journal of Research in Educational Psychology, 11(3), 851-882.

Frontini, R., Moreira, H., \& Cristina, M. (2016). Parenting Stress and Quality of Life in Pediatric Obesity : The Mediating Role of Parenting Styles. J Child Fam Stud, 1011-1023. https://doi.org/10.1007/s10826-015-0279-3

Gopal, S., \& Rai, Ashok. (2016). Parental stress and quality of life in parents of children with bronchial asthma. International Journal of Health Sciences and Research, 6, 293-300.

Jiun, C. X., Jaafar, W. M. W., \& Ghazali, N. M. (2016). The relationship between parenting stress and perceived children's social problem behavior among chinese working mothers. International Journal of Social Science and Humanity, 6(3), 157-164. 
Kementerian Kesehatan Republik Indonesia. (2020). Panduan Pelayanan Kesehatan Balita Pada Masa Pandemi Covid-19 Bagi Tenaga Kesehatan. Jakarta: Direktorat Kesehatan Keluarga Direktorat Jenderal Kesehatan Masyarakat.

Kochanova, K. (2014). Parenting stress among biological, adoptive, foster, and guardian parents of children with prenatal and/or environmental substance exposure. Proceedings of The National Conference.

Lewallen, Andrea. (2015). Parent Stress and Social Skills Development in Children with Developmental Delays. Loma Linda University.

Neece, C. L., Green, S. A., \& Baker, B. L. (2012). Parenting stress and child behavior problems: a transactional relationship across time. Am Journal Intellectual Developmental Disability, 117(1), 48-66. doi:10.1352/1944-7558-117.1.48.

Nomaguchi, K., Brown, . L. Leyman, T. M. (2017). Fathers' participation in parenting and maternal parenting stress: variation by relationship status. Journal Fam, 38(8): 1132-1156. doi:10.1177/0192513X15623586.

Santrock, J. W. (2012). Life-Span Development Perkembangan Masa Hidup13th ed. Jakarta: Erlangga.

Smith, Latoya M. (2009). Parent and Teacher Influences on Preschool Children's Emotion Regulation, Pre-Academic and Social Skills. The University of Alabama.

Tambunan, Liza. Dampak Sosial Virus Corona: Beban 'Berlipat Ganda' bagi Perempuan di Masa Pandemi Covid-19. BBC News Indonesia. 21 April 2020. Web 23 Juni 2020. https://www.bbc.com/indonesia/indonesia-52323527.

Asmundson, G.J.G., Taylor, S., 2020a. Coronaphobia: fear and the 2019-nCoV outbreak.Journal Anxiety Disorder, 70, 102-196.

Kiecolt-Glaser, J. K., McGuire, L., Robles, T. F., \& Glaser, R.(2002). Emotions, morbidity, and mortality: New perspectives from psychoneuroimmunology. Annu. Rev. Psychol., 53, 83-107.

McGuire, L., Kiecolt-Glaser, J. K., \& Glaser, R. (2002).Depressive symptoms and lymphocyte proliferation in olderadults. Journal Abnormal Psychology, 111, 192-197. 
Shigemura, J., Ursano, R.J., Morganstein, J.C., Kurosawa, M., Benedek, D.M., (2020). Public responses to the novel 2019 coronavirus (2019 - nCoV): mental health consequences and target populations. Psychiatry Clin. Neurosci.

Wang, C., Pan, R., Wan, X., Tan, Y., Xu, L., Ho, C.S., Ho, R.C. (2020). Immediate psychological responses and associated factors during the initial stage of the 2019 coronavirus disease (COVID-19) epidemic among the general population in China. Int. Journal Environ. Res. Public Health, 17 (5), 17-29. 